\title{
Opinnäytetyö mahdollisuutena ammatilliseen kasvuun - kirjasto- ja tietopalvelualan opinnäytteet Seinäjoen ammattikorkeakoulussa
}

Millainen on amk-opinnäytetyö verrattuna yliopiston graduun? Entä millaista on ottaa opinnäytetyöntekijä omaan organisaatioon tekemään tilaustyötä? Työpaikan toimeksiantaja ei ole yksin vastuussa ohjauksesta, jokaisella opinnäytetyön tekijäl-

lä on oma ohjaaja oppilaitoksen puolesta. Tässä artikkelissa

kuvataan tarkemmin, millaista on toimia opinnäytetyön toimeksiantajana. Toivomme tulevaisuudessa lisää toimeksiantoja tieteellisistä kirjastoista.

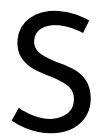
einäjoen ammattikorkeakoulu muodostuu kuudesta koulutusalasta. Yli 20 tutkinto-ohjelmasta valmistuu vuosittain opiskelijoiden ahkeran työn tuloksena mittava määrä, noin 800 opinnäytetyötä eri aloille. Näiden tutkinto-ohjelmien joukkoon lukeutuu myös kirjasto- ja tietopalveluala, jonka opinnäytetyöt ovat tärkeä tapa ylläpitää alan työelämäyhteyksiä, tarjota mahdollisuuksia tutkimus- ja kehittämistoimintaan sekä vahvistaa vuoropuhelua työelämän, alan opetuksen ja opiskelijoiden välillä.

\section{Opinnäytetyöt} asiantuntijuuden osoituksena Ammattikorkeakoulututkintoon johtavien opintojen keskeisenä tavoitteena on antaa tutkinnon suorittaneelle laaja-alaiset käytännölliset perustiedot ja -taidot sekä teoreettiset perusteet toimia työelämässä oman alansa asiantuntijatehtävissä (A I 8. I 2. 20 I 4/I I 29). Opetuksen työelämälähtöisyys ilmenee opiskelun aikana monipuolisena yhteistyönä työelämän kanssa niin oppimistehtävien, hankkeiden, asiantuntijavieraiden, harjoittelun kuin opinnäytetöiden kautta. Opintojen loppuvaiheeseen sijoittuva opinnäyte on sananmukaisesti näyte opiskelijan osaamisesta, jossa sovelletaan tutkintoon johtavassa opiskelussa hankittuja tietoja ja taitoja käytännön työelämänvaatimuksiin ja osoitetaan valmiutta itsenäisiin asiantuntijatehtäviin omalla koulutusalalla (AMK-tutkinnon opinnäytetyöohje 2020).

Ammattikorkeakouluille on tyypillistä, että opinnäytteet toteutetaan työelämälähtöisesti erilaisin toimeksiannoin. Valmistuvat työt voivat vaihdella kartoituksista kehittämistehtäviin, selvityksistä suunnitelmiin ja tutkimuksellisiin tuotoksiin. Ammattikorkeakoulussa työ voi olla muodoltaan tutkimuksellinen tai toiminnallinen. Opinnäytetyö on opintojen laajin yksittäinen harjoitustyö, jossa prosessimaisesti harjoitellaan asiantuntijan roolin ottamista, ongelmanratkaisua, projektimaista työskentelyä, tutkimuksellista työotetta, syvennetään 
ja sovelletaan tiedonhankintataitoja sekä harjoitellaan tutkimustulosten suullista ja kirjallista esittämistä.

Opinnäytetöitä tarkastellessa on hyvä muistaa, että jokaisen opiskelijan kasvuprosessi kohti asiantuntijuutta on erilainen ja valmiin lopputuloksen lisäksi oppilaitoksessa arvioinnin kohteena on koko työprosessi yhdeksän arviointiperusteen kautta aina aiheenvalinnasta valmiin työn esittämiseen asteikolla I-5 (Seinäjoen ammattikorkeakoulun opinnäytetöiden arviointikriteerit 2020). Virallisen arvioinnin rinnalla työn toimeksiantaja arvioi työtä suhteessa omien tavoitteidensa toteutumisen, yhteistyön sujumiseen ja tulosten hyödynnettävyyteen. Molempien tahojen palautteita tarvitaan opiskelijan kehittymiseksi, minkä lisäksi opiskelija saa myös vertaispalautetta ONT-seminaarissa koko työprosessinsa ajan. Opinnäytetöiden arvosanat eivät kuitenkaan ole julkista tietoa.

\section{Mukaan SeAMKin ONT. prosessiin}

Opinnäytetyön laajuus on I 5 opintopistettä, joka työtunneiksi muutettuna tarkoittaa reilua 400 työtuntia. Prosessi kestää tyypillisesti yhden lukuvuoden alkaen kevätlukukaudella ja päättyen valmistumiseen syyslukukauden lopussa. Opinnäytetyöprosessi aloitetaan Seinäjoella kolmannen opiskeluvuoden kevätlukukaudella, mutta opiskelijoita kannustetaan etsimään opinnäytetyöaiheita jo syyslukukaudelle sijoittuvan ammatillisen harjoittelun aikana. Otol- lisin aika ottaa yhteyttä meihin ja tarjota aiheita opiskelijoille onkin syksy tai viimeistään tammikuun alku.

Aihe-ehdotuksia voi tarjota tiedoksi tutkinto-ohjelmalle ja mikäli aihe täyttää opinnäytetyölle asetetut vaatimukset, niistä tiedotetaan edelleen opiskelijoille. Opiskelija tekee itse valinnan mahdollisten aiheiden joukosta, mutta kaikki aiheet tulee hyväksyttää tutkinto-ohjelman ohjaavalla opettajalla.

Vaikka ONT-prosessi on opiskelijan oma ja itsenäinen prosessi, sitä tuetaan SeAmkissa sekä henkilökohtaisella ohjauksella että opinnäytetyötä tukevilla opinnoilla (AMK-tutkinnon opinnäytetyöohje 2020). Kirjasto- ja tietopalvelualan tutkinto-ohjelmassa näitä opintoja ovat opinnäytetyöklinikka ja -seminaari 4 op, tutkimusmenetelmät 3 op sekä tiedonhaku 5 op (Tradenomi (Амк), Kirjasto- ja tietopalveluala). Toimeksiantajan puolesta kuitenkin riittää, että opiskelijalle on tarjolla työelämälähtöinen aihe, minkä jälkeen mahdollisesta osallistumisesta prosessin eri vaiheisiin sovitaan tapauskohtaisesti opinnäytetyösopimuksen kautta. Toimeksiantajaksi ryhtyminen ei siis edellytä erillistä työelämänohjausta, vaan jokaiselle opinnäytetyön tekijälle nimetään oma ohjaaja oppilaitoksen puolesta.

\section{Aiheiden kirjoa}

Tyypillisesti opinnäytteiden aiheet kumpuavat opiskelijoiden omasta kiinnostuksesta, harjoittelussa havaituis- 
ta kehittämiskohteista, aikaisemmasta työhistoriasta tai työelämän toimeksiannoista. Yleisten kirjastojen osuus alan merkittävimpänä työllistäjänä kuitenkin heijastuu selvästi opinnäytetöiden aihevalintoihin. SeAmkin opetuksessa on viime vuosina pyritty huomioimaan paremmin eri kirjastosektorit ja lisätty tieteellisten kirjastojen näkyvyyttä opinnoissa. Tutkinto-ohjelman toiveissa onkin monipuolistaa tätä yhteistyötä myös opinnäytteiden kautta.

Valmistuneiden töiden joukosta löytyy toki jo nyt tieteellisiä kirjastoja ja erikoiskirjastoja koskevaa tutkimuksia. Esimerkiksi Mari Myllyharju (2019) tarttui omassa työssään ajankohtaiseen teemaan ja selvitti ministeriöiden avoimien verkkojulkaisujen löydettävyyttä. Noora Väänänen (2020) selvitti työssään erikoiskirjastojen kokemuksia palveluidensa tunnettuudesta ja niiden kehittämistä. Erikoiskirjastojen toimintaan perehtyi niin ikään Sami Asikainen (2020) omassa työssään tutkien KAVI:n työntekijöiden näkemyksiä ja käyttäjäkokemuksia RITVA-tietokannasta. Asikaisen työ on lisäksi esimerkki ammatillisen harjoittelun pohjalta syntyneestä toimeksiannosta. Samankaltainen polku harjoittelusta aiheeksi löytyy Kaisa Märsyn (2020) työstä, jossa perehdyttiin Tiedekirjasto Tritonian saavutettavuusarviointiin.

Vuosien varrelta toimeksiantajien joukosta löytyy myös muun muassa Maanpuolustuskorkeakoulun kirjasto, AMKIT-konsortio, Lastenkirjainstituuttin kirjasto, SeAMKin korkeakoulu- kirjasto, Siirtolaisuusintituutin Pohjanmaan aluekeskus sekä Satakunnan keskussairaalan tieteellisen kirjasto. Aiheiden puolesta opiskelijoiden kestosuosikkeja ovat tiedonhankinta, kirjastopedagogiikka, markkinointi, kokoelmien kehittäminen ja erilaiset tenkin yllättää. Tutkimusta on tehty jopa lukukoiratoiminnan mahdollisuuksista korkeakouluympäristössä.

Keväällä 202 I alkaneen ONT-prosessin toimeksiantajien joukosta löytyvät tällä kertaa esimerkiksi Varastokirjasto, Laurea ja SeAMK, mutta mukaan joukkoon toivomme tulevaisuudessa vielä enemmän tieteellisiä kirjastoja. Jo valmistuneisiin ja valmistuviin SeAMK opinnäytetöihin voi tutustua kaikille avoimessa Theseus-tietokannassa. Tutkinto-ohjelmamme opetussuunnitelmaan pääsee tutustumaan avoimesti SeAMKin verkkosivuilta ja sen sisältöjä tarkastelemalla saa paremman käsityksen opiskelijoiden osaamisalueista (Tradenomi (Амк), Kirjasto- ja tietopalveluala). Kannattaa siis tutustua valmiisiin töihin Theseuksessa tai keskustella tutkinto-ohjelman opettajien kanssa oman organisaation tarpeista.

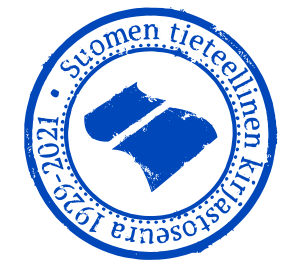




\title{
Löhteet
}

A I8. I 2. 20I4/I I 29. Valtioneuvoston asetus ammattikorkeakouluista.

AMK-tutkinnon opinnäytetyöohje, 2020. Seinäjoki: Seinäjoen ammattikorkeakoulu. Julkaisematon.

AsIKAINEN, S., 2020. RITVA-tietokanta: Kartoitus työntekijöiden näkemyksistä ja käyttäjäkokemuksista.

Seinäjoki: Seinäjoen ammattikorkeakoulu. Liiketoiminnan ja kulttuurin yksikkö, kirjastoja tietopalvelualan tutkinto-ohjelma. Opinnäytetyö.

http://urn.fi/URN:NBN:fi:amk-2020I0262I662

Myllyharju, M., 2019. Ministeriöiden avoimien verkkojulkaisujen löydettävyys: Tiedon tuottajasta tiedonhakijaan. Seinäjoki: Seinäjoen ammattikorkeakoulu. Liiketoiminnan ja kulttuurin yksikkö, kirjasto- ja tietopalvelualan tutkinto-ohjelma. Opinnäytetyö. http://urn.fi/URN:NBN:fi:amk-20I9I 20223856

MärsY, K., 2020. Tritonian Finna-hakupalvelun saavutettavuusarviointi. Seinäjoki: Seinäjoen ammattikorkeakoulu. Liiketoiminnan ja kulttuurin yksikkö, kirjasto- ja tietopalvelualan tutkinto-ohjelma. Opinnäytetyö. http://urn.fi/URN:NBN:fi:amk-2020 I I I 622997

Seinäjoen ammattikorkeakoulun opinnäytetöiden arviointikriteerit. 2020. Seinäjoki: Seinäjoen ammattikorkeakoulu. Julkaisematon.

Tradenomi (Амк), Kirjasto- ja tietopalveluala, Päivätoteutus 202I. Ei päiväystä. Seinäjoki: Seinäjoen ammattikorkeakoulu.

https://opinto-opas.seamk.fi/index.php/fi/2I/fi/55/KITI2I/year/202I

VÄÄNÄNEN, N., 2020. Kirjastopalveluiden tunnettuuden kehittäminen erikoiskirjastoissa. Seinäjoki: Seinäjoen ammattikorkeakoulu. Liiketoiminnan ja kulttuurin yksikkö, kirjastoja tietopalvelualan tutkinto-ohjelma. Opinnäytetyö.

http://urn.fi/URN:NBN:fi:amk-2020092320659

\author{
Satu Salmela \\ Seinäjoen ammattikorkeakoulu \\ (Kirjasto- ja tietopalvelualan tutkinto-ohjelma) \\ satu.salmela@seamk.fi
}

